\title{
Окремі питання оцінки захищеності вертольотів на етапі випробувань
}

\author{
Iгор Телевний * 1 А; Антон Козир 2 А; Павло Опенько ${ }^{3 \text { в }}$ \\ А Державний науково-дослідний інститут випробувань і сертифікації озброєння та військової техніки, вул. Стрілецька 1, м. Чернігів, 14033, Україна \\ в Національний університет оборони України імені Івана Черняховського, пр-кт Повітрофлотський 28, м. Київ, 03049, Україна
}

Received: June 7, 2021 | Revised: June 23, 2021 | Accepted: June 30, 2021

DOI: $10.33445 /$ sds.2021.11.3.12

\begin{abstract}
Анотація
Процес випробувань авіаційної техніки військового призначення, в тому числі i вертольотів, полягає в отриманні льотно-технічних характеристик, що характеризують даний зразок, та порівняння їх з характеристиками, заданими у тактико-технічному завданні. Однією з ключових вимог до системи захисту сучасних вертольотів $\epsilon$ зниження їх теплової помітності, що успішно реалізовується за допомогою встановлення екранновихлопних пристроїв. Основні характеристики екранно-вихлопних пристроїв, містять цілий спектр характеристик та факторів, які не лише потребують комплексного підходу в оцінці їх ефективності, а й постійно змінюються з урахуванням нових досягнень у зазначеній сфері. Тому питання удосконалення методик оцінки підсистеми екранно-вихлопних пристроїв на етапі випробувань вертольоту $є$ досить актуальним.

Оцінка відповідності вертольоту зі встановленими екранно-вихлопними пристроями вимогам тактико-технічного завдання, на етапі випробувань, неможлива без окремої методики, використання якої дозволить отримати єдиний підхід при визначенні ефективності комплексу захисту на передпроєктних та ранніх проєктних стадіях розробки (модернізації) систем захисту вертольотів, а також при випробуваннях систем захисту модернізованих та новітніх зразків вертолітної техніки.

Проблемним питанням оцінки захищеності вертольотів за рахунок зниження теплової помітності приділено увагу багатьох наукових досліджень та публікацій, як в Україні так i закордоном. Але існуючі підходи в неповній мірі враховують сучасні системи захисту, такі як екранно-вихлопні пристрої, що обмежує їх використання при проведенні випробувань нових та модернізованих зразків вертолітної техніки.

3 огляду на сучасний розвиток техніки, постає логічне питання оцінки захищеності вертольотів з врахуванням внеску підсистеми екранно-вихлопних пристроїв системи захисту на етапі їх випробувань.

У статті проведено аналіз основних складових, які визначають порядок вибору критеріїв оцінки ефективності комплексу захисту вертольоту з врахуванням вкладу підсистеми екранно-вихлопних пристроїв. Проведено аналіз ієрархічної структури вертольоту, представленого у вигляді складної технічної системи, яка складається з елементів, що визначають її властивості. Запропоновані шляхи удосконалення методик оцінки внеску екранно-вихлопних пристроїв у загальну систему захисту вертольоту при проведенні випробувань.
\end{abstract}

За результатами досліджень запропонована методика оцінки захищеності вертольоту з урахуванням внеску підсистеми екранно-вихлопних пристроїв системи захисту, яка дозволяє визначити найбільш слабкі властивості підсистеми, оцінити їі загальний рівень, який характеризується набором показників і розробити заходи для підвищення захищеності вертольоту.

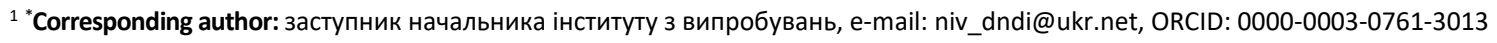

${ }^{2}$ к.т.н., начальник науково-дослідного відділу, e-mail: kozyrwork@ukr.net, ORCID: 0000-0002-1888-2553

3 к.т.н., старший дослідник, начальник науково-дослідного відділу інституту авіації та протиповітряної оборони, e-mail: pavel.openko@ukr.net, ORCID: 0000-0001-7777-5101
} 
Ключові слова: вертоліт; система; методика; випробування; екранно-вихлопний пристрій.

\section{Постановка проблеми}

Процес випробувань будь якої авіаційної техніки військового призначення, в тому числі і вертольотів, полягає в отриманні льотнотехнічних характеристик, що характеризують даний зразок, та порівняння їх 3 характеристиками, заданими у тактикотехнічному завданні. Однією з ключових вимог до системи захисту сучасних вертольотів $\epsilon$ зниження їх теплової помітності, що успішно реалізовується за допомогою встановлення екранно-вихлопних пристроїв. Основні характеристики екранно-вихлопних пристроїв, як складової системи захисту вертольотів містять цілий спектр не лише суто технічних характеристик, таких як потужність випромінювання, спектр випромінювання та інші, що вимірюються в лабораторних умовах, але й цілий ряд інших характеристик та факторів, які не лише потребують комплексного підходу в оцінці їх ефективності, а й постійно змінюються з урахуванням нових досягнень у зазначеній сфері. Тому питання удосконалення методик оцінки підсистеми екранно-вихлопних пристроїв на етапі випробувань вертольоту $є$ досить актуальним.

Очевидно, що для отримання комплексного висновку про відповідність вертольоту зі встановленими екранно-вихлопними пристроями вимогам тактико-технічного завдання, на етапі випробувань, необхідно удосконалити методики оцінки впливу екранно-вихлопних пристроїв на льотнотехнічні характеристики вертольоту шляхом розробки окремої методики, використання якої дозволить спростити та отримати єдиний підхід при визначенні ефективності комплексу захисту на передпроєктних та ранніх проєктних стадіях розробки (модернізації) систем захисту вертольотів, а також при випробуваннях систем захисту модернізованих та новітніх зразків вертолітної техніки.

\section{Аналіз останніх досліджень та публікацій}

Проблемним питанням оцінки захищеності вертольотів за рахунок зниження теплової помітності приділено увагу багатьох наукових досліджень та публікацій, як в Україні [1-4] так і закордоном [5-7]. Але існуючі підходи в неповній мірі враховують сучасні системи захисту, такі як екранно-вихлопні пристрої, що обмежує їх використання при проведенні випробувань нових та модернізованих зразків вертолітної техніки.

У монографії [1] розглянуті роль і тенденції розвитку систем захисту повітряних об'єктів від ракет 3 інфрачервоним самонаведенням, проаналізовані різні аспекти застосування та ефективності означених систем.

У роботах [2-4] основна увага приділена розробці математичних моделей показників ефективності вертолітної техніки. Проведено аналіз програмно-методичного апарату на різних етапах випробувань модернізованої вертолітної техніки.

У публікаціях [5-7] розглядаються сучасний методичний підхід до вирішення завдання визначення теплової та інфрачервоної помітності шляхом комп'ютерного моделювання.

\section{Постановка завдання}

Основні характеристики систем захисту вертольоту від керованих ракет 3 інфрачервоними головками самонаведення крім суто технічних параметрів, таких як потужність випромінювання, спектр випромінювання та інше, що вимірюються в лабораторних умовах, містять імовірнісні характеристики, наприклад імовірність невлучання ракети у ціль. 3 огляду на сучасний розвиток техніки, постає логічне питання оцінки захищеності вертольотів 3 врахуванням внеску підсистеми екранновихлопних пристроїв системи захисту на етапі їх випробувань. 
Метою статті $\boldsymbol{\epsilon}$ формування методики оцінки захищеності вертольоту з урахуванням внеску підсистеми екранно-вихлопних пристроїв системи захисту з подальшою ії апробацією на практиці.

\section{Виклад основного матеріалу}

Однією з основних властивостей бойової ефективності вертольоту $є$ його захищеність. Цю властивість характеризує здатність вертольота виконувати свої функції за призначенням в умовах дії засобів противника: виявлення, прицілювання і ураження. В свою чергу, складовими захищеності вертольоту $€$ характеристики бойової живучості, помітності, придушення засобів протиповітряної оборони.

Основні зусилля розробників захисту вертольотів спрямовані на зниження теплової помітності та створення нових типів систем, які впливають на керовані засоби ураження. В умовах сьогодення, при проєктуванні систем захисту вертольоту та у сучасних дослідженнях [5-7], широко використовуються методи програмного моделювання процесів їх роботи [5], як це зображено на рисунку 1. Разом з тим, остаточну оцінку відповідності характеристикам, заданими у тактикотехнічному завданні, можливо зробити лише під час проведення практичних випробувань (рис. 2), результати яких можуть іноді кардинально відрізняються від прогнозованих характеристик.

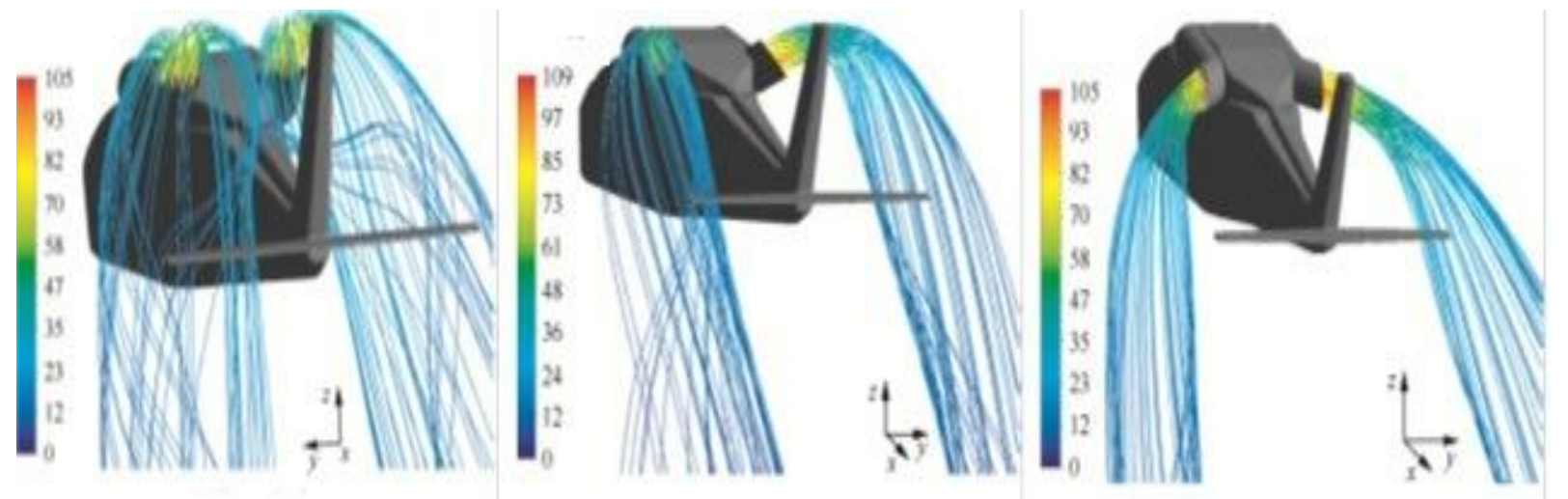

Рисунок 1 - Результати моделювання розсіювання теплового потоку вертольоту

Розробка методики оцінки захищеності вертольоту з урахуванням внеску підсистеми екранно-вихлопних пристроїв системи захисту потребує проведення аналізу ієрархічної структури вертольоту, як складної системи.

Аналіз ієрархічної структури являє собою систематичну процедуру для ієрархічно представленої складної технічної системи, яка складається з елементів, що визначають їі властивості. Зазначений аналіз полягає в декомпозиції системи на більш прості складові частини, з подальшим поетапним парним порівнянням показників системи 3 такими значеннями показників, які $\epsilon$ кращими для системи даного рівня складності і визначеного функціонального призначення. Це найкраще поєднання показників, можливо назвати раціональними значеннями складної технічної системи.

В загальному випадку завдання зводиться до поетапного встановлення співвідношення між значеннями, які аналізуються та раціональними значеннями. Таким чином, кожна з властивостей дослідного зразка вертольоту оцінюються за допомогою свого показника. Показник, який оцінює всю структуру своїх властивостей, називається комплексним. Подібно до властивостей, кожен показник може виступати, як комплексний по відношенню до показників власної структури для нижчих від нього 
ієрархічних рівнів, і водночас, як частковий по відношенню до вищих ієрархічних рівнів.

Значення показника кожної з властивостей дослідного зразка вертольоту залежить від технічних характеристик та умов, в яких вони оцінювались.

Зважаючи на цю умову, кожен з показників може визначатись, як для конкретних умов (виконання типових завдань), так і для часткової або всієї сукупності умов. Але слід зазначити, що така процедура може застосовуватись лише для тих властивостей системи, які можуть бути оцінені або виражені кількісно.

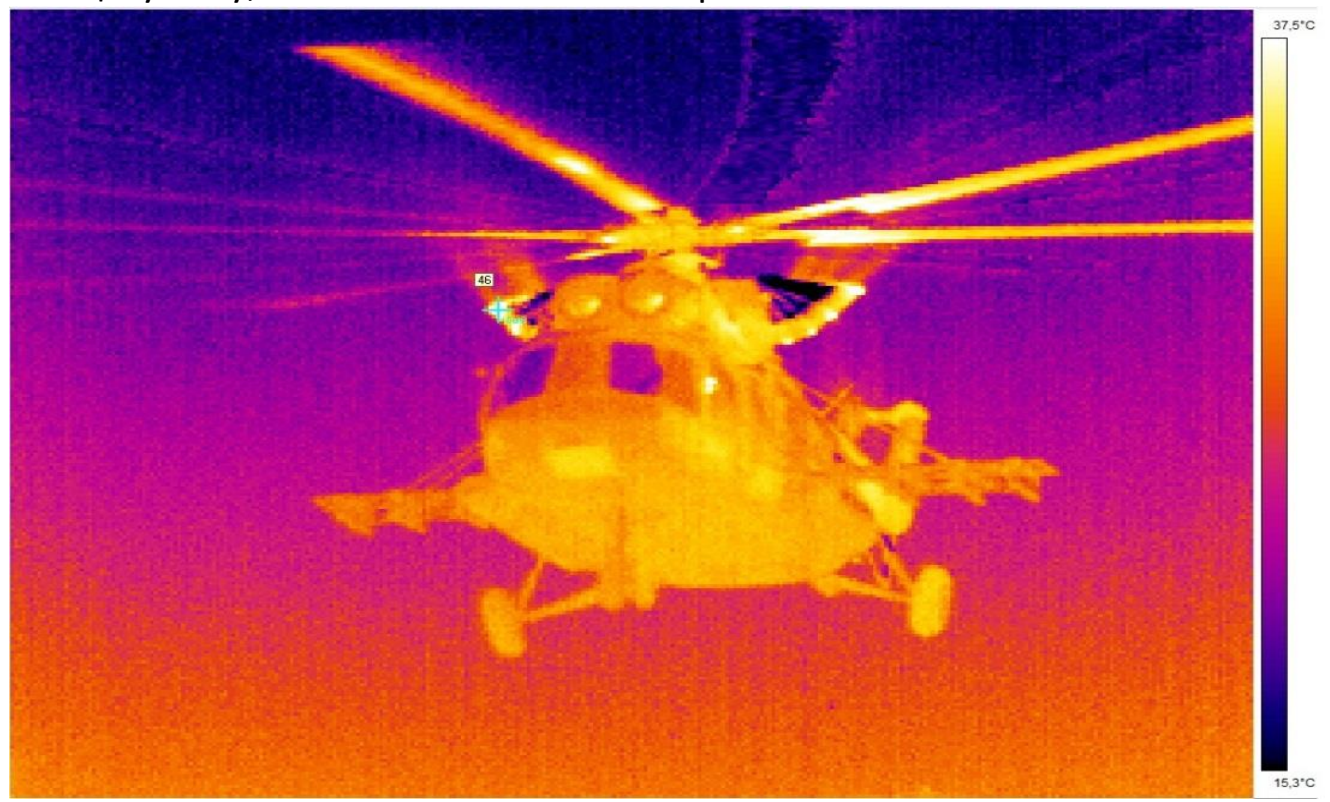

Рисунок 2 - Результати практичних замірів теплової помітності вертольоту з встановленими екранно-вихлопними пристроями під час проведення випробувань

Нехай $€ n$ показників, які характеризують властивості на k-му ієрархічному рівні складної технічної системи. Відповідно до викладеного методу порівняння у міру раціональності, порівнявши кожен $3 n$ показників з його раціональними значеннями отримаємо $n$ оцінок показника $R_{i}^{k}$ на $k$-му ієрархічному рівні. Кожна з цих оцінок $R_{i}^{k}$ характеризуватиме відносний рівень по даному показнику. Для наочності аналізу результат зручно представляти у вигляді гістограми (рис. 3).

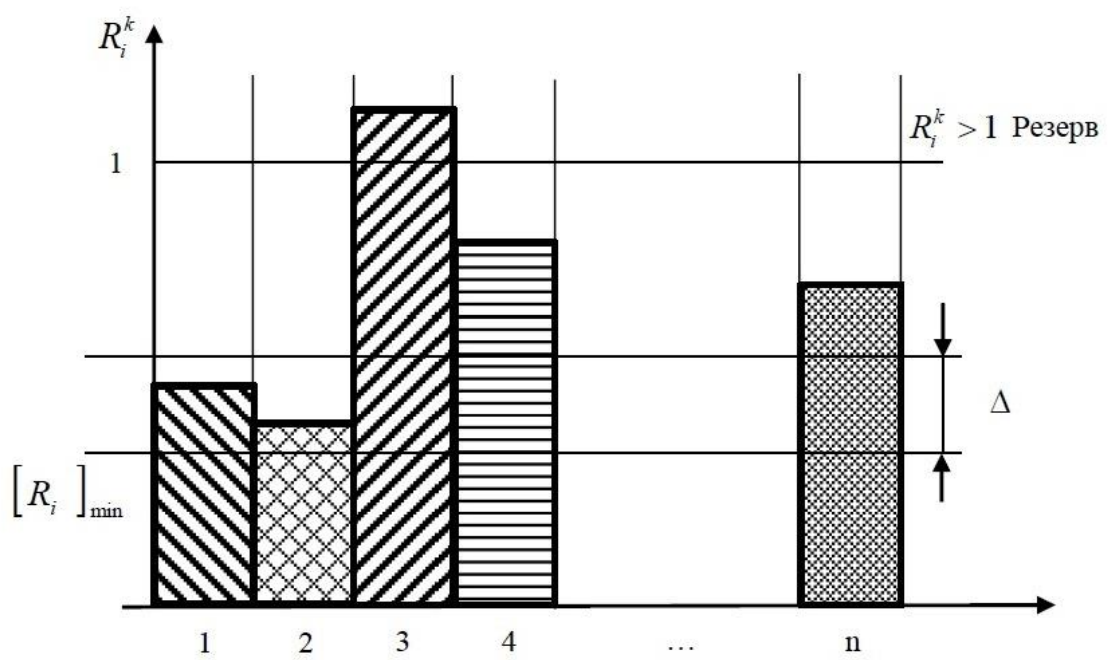

Рисунок 3 - Приклад побудови гістограми оцінок показників 
Аналіз даних такого роду дозволяє:

- виявити найбільш слабкі властивості;

- визначити властивості, при яких присутній резерв, коли $R_{i}^{k}>1$;

- оцінити загальний рівень підсистеми, яка характеризується даним набором показників.

Найбільш слабкою властивістю підсистеми буде та, яка має найменше значення з $R_{i}^{k}$. Причому, якщо встановити деякий діапазон

$$
\left[R_{i}^{k}\right]_{\min }+\Delta
$$

отримаємо можливість виявити групу властивостей, які мають недостатній рівень. Для таких властивостей значення $R_{i}^{k}$ знаходитимуться в межах

$$
\left[R_{i}^{k}\right]_{\min } \leq R_{i}^{k} \leq\left[R_{i}^{k}\right]_{\min }+\Delta .
$$

Отримані таким чином властивості становлять інтерес з точки зору розробки заходів для їх підвищення, але здійснювати ці заходи доцільно лише після ретельного i всебічного аналізу ваги цих властивостей, їх впливу на тактико-технічні властивості вертольоту в цілому і 3 врахуванням можливого інтеграційного ефекту, який може бути позитивним (підвищити властивості без наслідків) або негативним (одна чи група властивостей підвищились, а решта зменшились).

Друга група властивостей - це ті, при яких присутній резерв, для них $R_{i}^{k}>1$.

Ця група властивостей цікава, по-перше, визначенням структурних елементів, які на даному етапі розвитку техніки не мають потреби у доопрацюваннях, а по-друге підвищеною увагою до них, як до непрямих ознак можливих якісних змін. Саме тому, визначивши такі показники, слід провести аналіз відносно прогнозів розвитку і оцінки часового ресурсу збереження резерву.

Такий аналіз може бути виконаний на основі розроблених методів науковотехнічного прогнозу.

Загальний рівень підсистеми, яка характеризується $n$ показниками, визначається їх сумою.

Зазначена процедура проводиться для всіх показників, як одиничних, так і комплексних, і на підставі аналізу результатів визначаються елементи структури, які знижують її рівень та наявний резерв, а також загальний рівень по підсистемам. У даному дослідженні, у відповідності до ієрархічної структури вертольоту і відповідною структурою ієрархії показників, такий аналіз виконується для одиничних базових, питомих і комплексних показників, на підставі чого були отримані інтегральні оцінки рівня захищеності вертольоту.

Враховуючи багаторівневу ієрархію вертольоту, необхідно окремо зупинитись на оцінці впливу підсистем на загальні характеристики об'єкту.

Розробка підсистем супроводжується прагненням забезпечити найбільш можливу ефективність захисту вертольоту, як системи, нерідко навіть у збиток оптимізації підсистем. Для виконання такого проєктування необхідний апарат і інформація, які дозволяють оцінити вплив зміни показників підсистем на загальний технічний рівень та ефективність.

У разі, коли задачі верхнього та нижнього ієрархічного рівня вирішуються окремо, такий апарат і інформація можуть бути продуктом вирішення задачі оптимізації елементів вертольоту.

Саме тому, природньою $€$ вимога щодо використання на нижньому та верхньому рівнях при проєктуванні однакових підходів і показників, а також єдиних критеріїв для порівняння варіантів. Разом 3 тим, 3 урахуванням великої кількості прямих і зворотних зв'язків цього недостатньо. Зважаючи на цю обставину, введені загальні показники і на проміжних ієрархічних рівнях, які при зміні показників верхнього і нижнього рівня повинні інформувати, насамперед, про погіршення властивостей підсистеми.

Окрім того, важливо враховувати ряд особливостей, до яких слід віднести:

- при проєктуванні вертольоту можлива оптимізація підсистем, тобто визначення кращих характеристик у відповідності 3 цільовою функцією;

- не всі підсистеми створюються разом і для даного об'єкту (запозичені вироби, 
складові частини, комплектуючі тощо).

Перша особливість важлива, як постулат системотехніки про те, що система, яка складена з оптимальних систем, не $\epsilon$ оптимальною. Тому методи оптимізації, в принципі, мають обмежене застосування для складних систем.

Друга зі згаданих вище особливостей, обмежує втручання проєктувальника у зміну показників. В такому випадку часто буває достатнім при розгляді альтернативних варіантів прямо оцінити вплив підсистеми на характеристики вертольоту.

В цілому, в умовах відсутності єдиного підходу до оцінки варіантів проєктів або порівняння захищеності вертольоту, в якості критеріїв ефективності або вибору варіанта можуть бути прийняті показники, що відображають точку зору осіб, які приймають рішення по конкретній підсистемі або об'єкту в цілому. Ця обставина - додатковий аргумент необхідності розробки єдиного підходу до аналізу варіантів і порівняння зразків, який $€$ інструментом забезпечення системних принципів, як проєктування, так і захищеності вертольоту.

3 урахуванням вищенаведеного, захищеність вертольоту розділимо на критерії і підкритерії.

До основних критеріїв віднесемо: бойову живучість; маневреність; помітність; засоби захисту.

До бойової живучості відносяться пасивні засоби захисту і є підкритеріями:

- найменш уразливе для засобів ураження розташування важливих агрегатів і вузлів на вертольоті, захист їх менш важливими елементами;

- застосування вогнестійкої проводки управління з рознесеними посиленими тягами;

- резервування найбільш важливих агрегатів і вузлів вертольоту, що сприяє продовженню виконання завдання при бойових пошкодженнях;

- бронювання кабіни екіпажу

найважливіших агрегатів;

- захист паливних баків від вибуху і витоків палива;

- засоби спасіння екіпажу;

- системи пожежогасіння.

До маневреності відносяться:

- максимальні перевантаження;

- максимальні швидкості польоту.

Помітність включає в себе:

- маскувальне (камуфляжне, деформуюче) забарвлення, у тому числі 3 малим коефіцієнтом віддзеркалення в оптичному діапазоні електромагнітних хвиль;

- покриття, які поглинають електромагнітні хвилі засобів виявлення і прицілювання противника в інфрачервоному i радіодіапазонах;

- зменшення ефективної поверхні розсіювання електромагнітних хвиль;

- зменшення теплової помітності вертольоту;

- зменшення акустичної помітності вертольоту.

До засобів захисту відносяться:

- системи попередження про електромагнітне опромінювання 3 боку супротивника засобами прицілювання і виявлення;

- системи постановки активних радіолокаційних перешкод засобам виявлення і прицілювання противника;

- системи відведення засобів ураження противника;

- дія електромагнітного імпульсу, що порушує роботу детонаторів засобів поразки противника;

- системи активного захисту, що виявляють і руйнують засоби ураження супротивника при їх підльоті до вертольоту;

- постановка димових і аерозольних перешкод.

Побудуємо ієрархію, починаючи з мети через основні критерії і яка закінчується підкритеріями (рис. 4), і в результаті отримаємо 4 основних критеріїв і 20 підкритеріїв. 


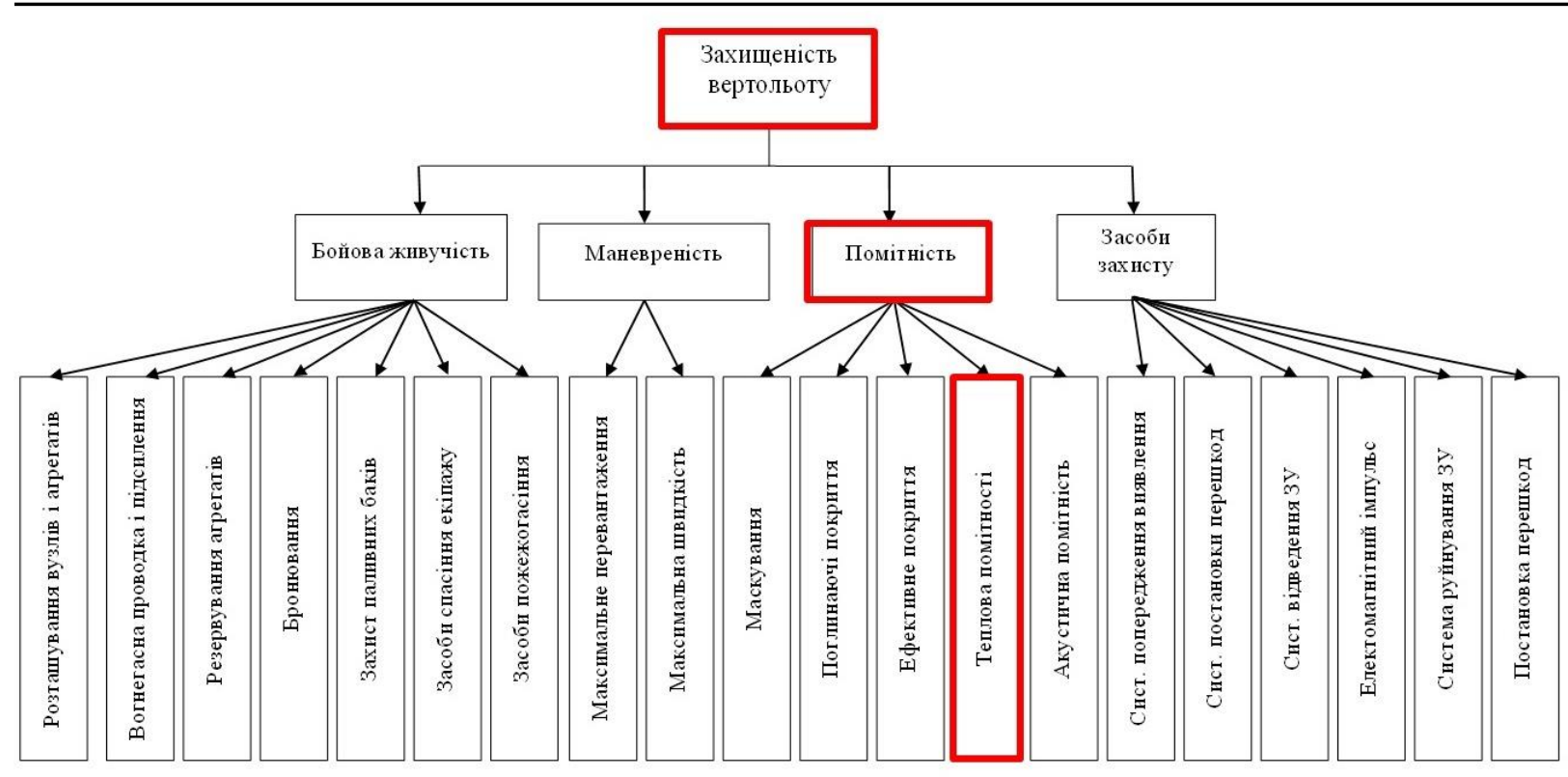

Рисунок 4 - Ієрархія захищеності вертольоту з урахуванням внеску підсистеми екранно-вихлопних пристроїв

Як ми можемо побачити з рисунку 4, урахування внеску підсистеми екранновихлопних пристроїв через зниження теплової помітності безпосередньо впливає на захищеність вертольоту.

\section{Висновки}

За результатами досліджень, запропонована методика оцінки захищеності вертольоту з урахуванням внеску підсистеми екранно-вихлопних пристроїв системи захисту, яка дозволяє визначити найбільш слабкі властивості підсистеми, оцінити їі загальний рівень, який характеризується набором показників і розробити заходи для підвищення захищеності вертольоту. На прикладі вертольоту, як складної системи, побудовано ієрархію його захищеності, яка містить 4 основних критерії та 20 підкритеріїв.

Використання результатів досліджень на практиці, дозволить виявити специфіку процесу функціонування підсистем системи захисту вертольоту та правильно організувати експеримент з метою отримання надійної інформації при мінімальній витраті коштів під час проведення випробувань нових та модернізованих зразків.

\section{Список використаних джерел}

1. Захист повітряних об'єктів від ракет 3 інфрачервоним самонаведенням / Кравчук І. С., Архипов М. І., Туренко С. М., Штарнов В.І.Київ: ТОВ “Видавничий дім “Інтернаука", 2020. 295 с.

2. Леонтьєв О.Б. Побудова математичної моделі показників якості вертольоту армійської авіації при вирішенні ним десантних задач / О.Б.Леонтьєв, Ю.І. Миргород, М.М. Момот // Збірник наукових праць ОНДІ ЗСУ. - 2007. - № 1 (6). - C. 14-21.
3. Башинський В.Г. Підвищення захищеності вертольотів при проведенні їх модернізації / В. Г. Башинський, Р. Г. Шабан, С. М. Туренко, О.Б. Котов // Харків. Науковий журнал. Системи озброєння і військової техніки. № 3(23) 2010. - с. 22-25.

4. Башинский В.Г. Методика определения инфракрасного излучения двигателей летательного аппарата при проведении испытаний / В. Г. Башинский, Ю. А. Камак // Науково-практичний журнал. Інтегровані технології та енергозбереження. №1. 2011. 


\section{- C. 76-81.}

5. Zhang JZ, Pan CX, Shan Y. Progress in helicopter infrared signature suppression. Chin J Aeronaut, Volume 27, Issue 2, 2014, Pages 189199.

6. Pan CX, Zhang JZ, Shan Y. Modeling and analysis of helicopter thermal and infrared radiation. Chin J Aeronaut 2011;24(5): 558-67.

7. Pan CX, Zhang JZ, Shan Y. Effects of exhaust temperature on helicopter infrared signature. Appl Therm Eng 2013;51:529-38.

\title{
Отдельные вопросы оценки защищенности вертолетов на этапе испытаний
}

\author{
Игорь Телевный * 1 А; Антон Козырь 2 А; Павел Опенько 3 в \\ * Corresponding author: ${ }^{1}$ заместитель начальника института по испытаниям, e-mail: niv_dndi@ukr.net, ORCID: 0000-0003-0761-3013 \\ ${ }^{2}$ к.т.н., начальник научно-исследовательского отдела, e-mail: kozyrwork@ukr.net, ORCID: 0000-0002-1888-2553 \\ ${ }^{3}$ к.т.н., старший исследователь, начальник научно-исследовательского отдела института авиации и противовоздушной обороны, е-таі:: \\ pavel.openko@ukr.net, ORCID: 0000-0001-7777-5101 \\ А Государственный научно-исследовательский институт испытаний и сертификации вооружения и военной техники, Украина

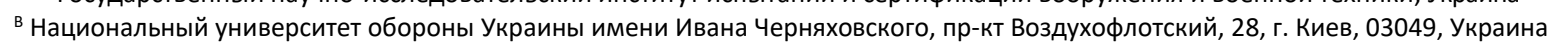

\section{Аннотация}

Процесс испытаний авиационной техники военного назначения, в том числе и вертолетов, заключается в получении летно-технических характеристик, характеризующих данный образец, и сравнения их с характеристиками, заданными в тактико-техническом задании. Одним из ключевых требований к системе защиты современных вертолетов является снижение их тепловой заметности, которое успешно реализуется посредством установления экранно-выхлопных устройств. Основные характеристики экранновыхлопных устройств, содержат целый спектр характеристик и факторов, которые не только требуют комплексного подхода в оценке их эффективности, но и постоянно меняются с учетом новых достижений в указанной сфере. Поэтому вопросы совершенствования методик оценки подсистемы экранно-выхлопных устройств на этапе испытаний вертолета является весьма актуальным.

Оценка соответствия вертолета с установленными экранно-выхлопными устройствами требованиям тактико-технического задания на этапе испытаний, невозможна без отдельной методики, использование которой позволит получить единый подход при определении эффективности комплекса защиты на предпроектных и ранних проектных стадиях разработки (модернизации) систем защиты вертолетов, а также при испытаниях систем защиты модернизированных и новых образцов вертолетной техники.

Проблемным вопросом оценки защищенности вертолетов за счет снижения тепловой заметности уделено внимание многих научных исследований и публикаций, как в Украине так и за рубежом. Но существующие подходы в неполной мере учитывают современные системы защиты, такие как экранно-выхлопные устройства, ограничивает их использование при проведении испытаний новых и модернизированных образцов вертолетной техники.

Учитывая современное развитие техники, возникает логичный вопрос оценки защищенности вертолетов с учетом взноса подсистемы экранно-выхлопных устройств системы защиты на этапе их испытаний.

В статье проведен анализ основных составляющих, которые определяют порядок выбора критериев оценки эффективности комплекса защиты вертолета с учетом вклада подсистемы экранно-выхлопных устройств. Проведен анализ иерархической структуры вертолета, представленного в виде сложной технической системы, которая состоит из элементов, определяющих ее свойства. Предложены пути совершенствования методик оценки вклада экранно-выхлопных устройств в общую систему защиты вертолета при проведении испытаний. 
По результатам исследований предложена методика оценки защищенности вертолета с учетом вклада подсистемы экранно-выхлопных устройств системы защиты, которая позволяет определить наиболее слабые свойства подсистемы, оценить ее общий уровень, который характеризуется набором показателей и разработать меры по повышению защищенности вертолета.

Ключевые слова: вертолет; система; методика; испытания; экранно-выхлопное устройство.

\title{
Specific issues of assessment of helicopters security at the test stage
}

\author{
Ihor Televnyi * 1 A; Anton Kozyr ${ }^{2}$ A; Pavlo Open'ko 3 B \\ *Corresponding author: ${ }^{1}$ Deputy Chief of Institute (on Testing), e-mail: niv_dndi@ukr.net, ORCID: 0000-0003-0761-3013 \\ 2 Ph.D. in Technical Science, Head of the Scientific-research Department, e-mail: kozyrwork@ukr.net, ORCID: 0000-0002-1888-2553 \\ ${ }^{3}$ Ph.D.in Technical Science, Senior researcher, Head of the Scientific-research Department of the Aviation and Air Defence Institute, e-mail: \\ pavel.openko@ukr.net, ORCID: 0000-0001-7777-5101

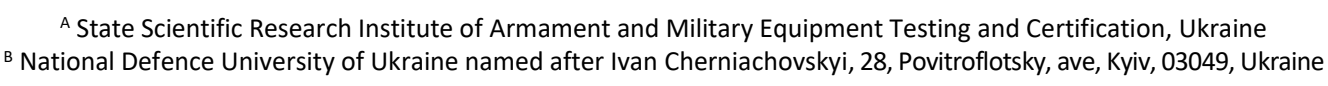

\begin{abstract}
The process of testing any military aircraft, including helicopters, is to obtain the parameters (flight characteristics) that characterize this sample, and compare them with the parameters specified in the request for proposal. One of the key requirements for the protection system of modern helicopters is to reduce their thermal visibility, which is successfully implemented through the installation of screen-exhaust devices. The main characteristics of screen-exhaust devices contain a range of parameters and factors that not only require a comprehensive approach to assessing their effectiveness, but also constantly changing in the light of new developments in this area. Therefore, the question of improving the methods of assessment of the subsystem of screen-exhaust devices at the stage of testing the helicopter is quite relevant. Assessment of compliance of the helicopter with the installed screen-exhaust devices to the requirements of the tactical and technical task, at the testing stage, is impossible without a separate method, the use of which will provide a unified approach to determining the effectiveness of protection at pre-design and early design stages of development (modernization) also when testing protection systems of modernized and newest models of helicopter equipment.

Many scientific researches and publications, both in Ukraine and abroad, have been paid attention to the problem of assessing the security of helicopters by reducing thermal visibility. But existing approaches do not fully take into account modern protection systems, such as screen-exhaust devices, which limits their use in testing new and upgraded models of helicopters.

Given the current development of technology, there is a logical question of assessing the security of helicopters, taking into account the contribution of the subsystem of screen-exhaust devices of the protection system at the stage of their testing.

The article analyzes the main components that determine the order of selection of criteria for evaluating the effectiveness of the helicopter protection system, taking into account the contribution of the subsystem of screen-exhaust devices. The analysis of the hierarchical structure of the helicopter, presented in the form of a complex technical system, which consists of elements that determine its properties. Ways to improve the methods of assessing the contribution of screen-exhaust devices to the overall protection system of the helicopter during the tests are proposed.

According to the research results, a method of helicopter security assessment is proposed taking into account the contribution of the screen-exhaust device subsystem of the protection system, which allows to determine the weakest properties of the subsystem, assess its overall level, characterized by a set of indicators and develop measures to improve helicopter security.
\end{abstract}


Keywords: helicopter; system; method; test; screen-exhaust device.

\section{References}

1. Zakhyst povitrianykh obiektiv vid raket $z$ infrachervonym samonavedenniam / Kravchuk I. S., Arkhypov M. I., Turenko S. M., Shtarnov V. I. Kyiv: TOV "Vydavnychyi dim "Internauka", 2020. 295.

2. Leontiev O. B. Pobudova matematychnoi modeli pokaznykiv yakosti vertolotu armiiskoi aviatsii pry vyrishenni nym desantnykh zadach / O. B. Leontiev, Yu. I. Myrhorod, M. M. Momot // Zbirnyk naukovykh prats ONDI ZSU. - 2007. - № 1 (6). - C. 14-21.

3. Bashynskyi V. H. Pidvyshchennia zakhyshchenosti vertolotiv pry provedenni yikh modernizatsii/ V. H. Bashynskyi, R. H. Shaban, S. M. Turenko, O. B. Kotov // Kharkiv. Naukovyi zhurnal. Systemy ozbroiennia i viiskovoi tekhniky. № 3(23) 2010. - c. 22-25.
4 Bashynskyi V. H. Metodika opredeleniya infrakrasnogo izlucheniya dvigatelej letatel'nogo apparata pri provedenii ispytanij / V. H. Bashynskyi, Yu. A. Kamak // Naukovopraktichnij zhurnal. Integrovani tekhnologiï ta energozberezhennya. № 1, 2011, 76-81.

5. Zhang JZ, Pan CX, Shan Y. Progress in helicopter infrared signature suppression. Chin J Aeronaut, Volume 27, Issue 2, 2014, Pages 189-199.

6. Pan CX, Zhang JZ, Shan Y. Modeling and analysis of helicopter thermal and infrared radiation. Chin J Aeronaut 2011;24(5): 55867.

7. Pan CX, Zhang JZ, Shan Y. Effects of exhaust temperature on helicopter infrared signature. Appl Therm Eng 2013; 51:529-38. 